\title{
Primary Pulmonary Actinomycosis Mimicking Malignancy
}

\author{
Maligniteyi Taklit Eden Primer Pulmoner Aktinomikoz Olgusu \\ ๑ Pınar Mutlu, • Nihal Arzu Mirici, ๑ Merve Illçin Güven \\ Çanakkale 18 Mart University Faculty of Medicine, Department of Chest Diseases, Çanakkale, Turkey
}

\begin{abstract}
The diagnosis of primary pulmonary actinomycosis (PPA) is still an important challenge in clinical practice due to its clinical and radiographic similarity with other infections and malignant diseases. Currently, the diagnosis can be only made histopathologically. A 67-year-old male patient was admitted to our clinic with the complaints of cough and hemoptysis for the past two months. His physical examination was non-specific. An increased non-homogeneous density was observed in the middle zone of the left hemithorax on chest X-ray. Thoracic computed tomography revealed a hypodense mass. Positron emission tomography revealed a hypermetabolic activity in the malignant mass. The patient was diagnosed with pulmonary actinomycosis through transthoracic fine needle aspiration biopsy. In conclusion, PPA should be considered in the differential diagnosis in patients with malignancy in the presence of predisposing risk factors.
\end{abstract}

Keywords: Actinomycosis, pulmonary, malignancy
Primer pulmoner aktinomikoz (PPA) tanısı klinik ve radyolojik olarak diğer enfeksiyonlara ve malign hastalıklara benzediği için pratikte hala önemli bir sorundur. Olgular ancak histopatolojik olarak tanı alabilmektedir. Altmış yedi yaşında erkek hasta iki aydır süren öksürük ve hemoptizi yakınmaları ile kliniğimize başvurdu. Fizik muayenede özellik yoktu. Akciğer grafisinde sol hemitoraks orta zonda nonhomojen dansite artımı saptandı. Toraks bilgisayarlı tomografisinde hipodens kitle saptandı. Pozitron emisyon tomografisinde kitlede malign karakterde hipermetabolik tutulum mevcuttu. Transtorasik ince iğne biyopsisi ile hastaya pulmoner aktinomikoz tanısı kondu. Bu olgu sunumunda malignite şüphesi olan hastaların predispozan risk faktörleri varlığında, ayıııcı tanısında PPA da bulunması gerektiği vurgulanmıştır.

Anahtar Sözcükler: Aktinomikosiz, pulmoner, malignite

\section{Introduction}

Actinomycosis is a chronic, granulomatous, and suppurative bacterial infection caused by Actinomyces spp., Gram-positive anaerobic bacteria (1). It was first described by Israel in 1878. It is an endogenous infection and occurs as a result of the penetration of actinomycetes in the normal flora to the mucous membrane damaged for various reasons. Actinomyces israelii is the most prevalent species isolated in human infections and is isolated from the mucosal surfaces of the tonsillar crypts, oral cavity including dental plaques, and gastrointestinal and female genital tracts (2). The main clinicopathological presentations of actinomycosis are cervicofacial (50\%), pulmonary $(15 \%)$, abdominopelvic (20\%), and central nervous system infections (2\%). Cutaneous, cardiac, and genitourinary system actinomycoses have also been reported in the literature (3). Microbiological and histopathological examination findings, as well as clinical manifestations, are helpful for the diagnosis. In the microbiological examination, reproduction can be seen in anaerobe cultures. Histopathological examination is, however, superior to the other diagnostic methods (4).

Herein, we present a case of primary pulmonary actinomycosis (PPA) with clinical and histopathological findings mimicking lung cancer in the light of the literature data.

\section{Case}

A 67-year-old male patient with a history of 30 pack-year smoking was admitted to our clinic with the complaints of cough and hemoptysis for two months. An increased non-homogeneous density was observed in the 
middle zone of the left hemithorax on chest X-ray. Thoracic computed tomography (CT) revealed a 3-cm hypodense mass. Initially, he was diagnosed with malignancy and was referred to our hospital for definitive diagnosis. His medical history was non-specific except tooth extraction. He was a farmer and cattle breeder. His general condition was good and he was hemodynamically stable. All other system examination findings were normal. However, he had a poor oral hygiene. In the complete blood count analysis, erythrocyte sedimentation rate was $65 \mathrm{~mm} / \mathrm{h}$ and white blood cell was $11.200 / \mathrm{mm}^{3}$. Biochemical analysis showed no abnormality other than elevated C-reactive protein values. Intense polymorphonuclear leukocytes were present in the sputum gram stain. There was no reproduction in the culture. No acid-resistant bacilli were found in the sputum. Posteroanterior (PA) chest $X$-ray revealed an increased non-homogeneous density in the left mid-peripheral lung (Figure 1). On thoracic CT, an approximately $3-\mathrm{cm}$ peripheral mass was seen in the superior segment of the left lower lobe (Figures 2, 3). Amoxicillin+clavulanic acid treatment was initiated for 10 days. Positron emission tomography (PET) was obtained, when the patient showed no regression, as assessed by PA chest $X$-ray. On PET, a malignant pleural hypermetabolic lesion with an increased fluorodeoxyglucose uptake in about $32 \times 21 \mathrm{~mm}$ in size (suv-max 7.4), which led to the pleural retraction in the superior segment of the left lower lobe (Figure 4). Transthoracic fine needle aspiration biopsy (TFNAB) was performed. The patient was diagnosed with PPA due to the presence of filamentous microorganisms compatible with actinomycetes in the fibrino-leukocytic exudate in the focal area and acute organizing pneumonia

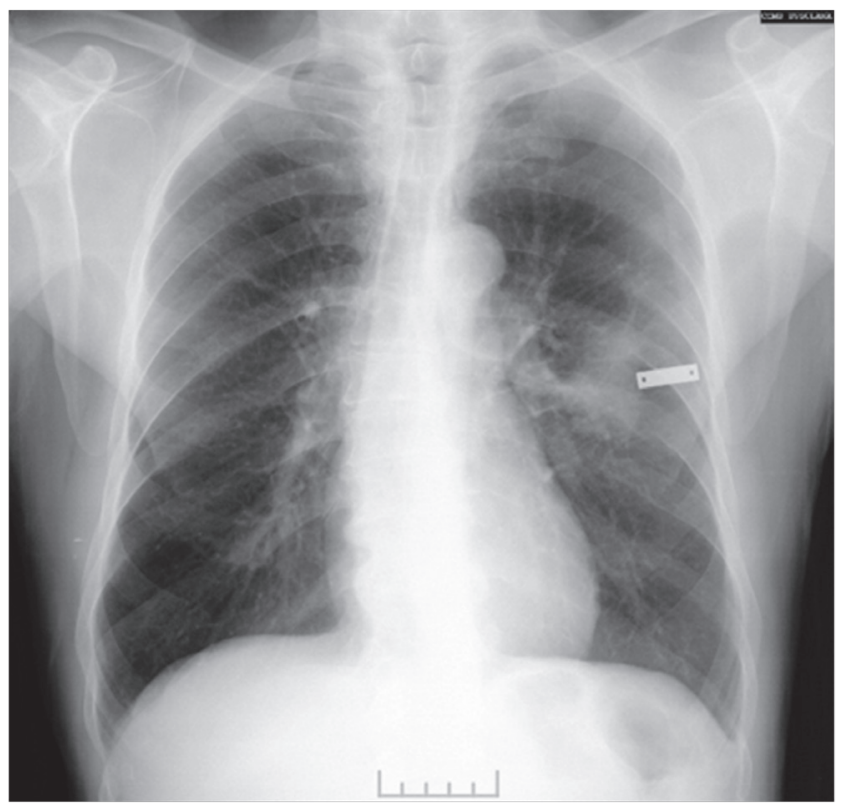

Figure 1. Posteroanterior chest X-ray progressing to a chronic state in the histopathological examination of TFNAB material (Figure 5,6 )

The patient was treated with parenteral sulbactam+ampicillin for 15 days and amoxicillin clavulanic

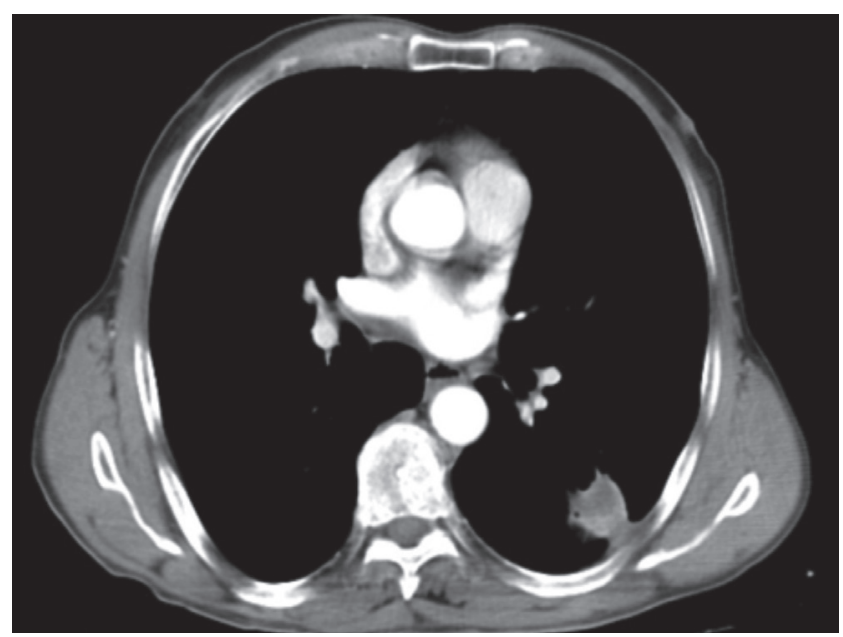

Figure 2. Thoracic computed tomography

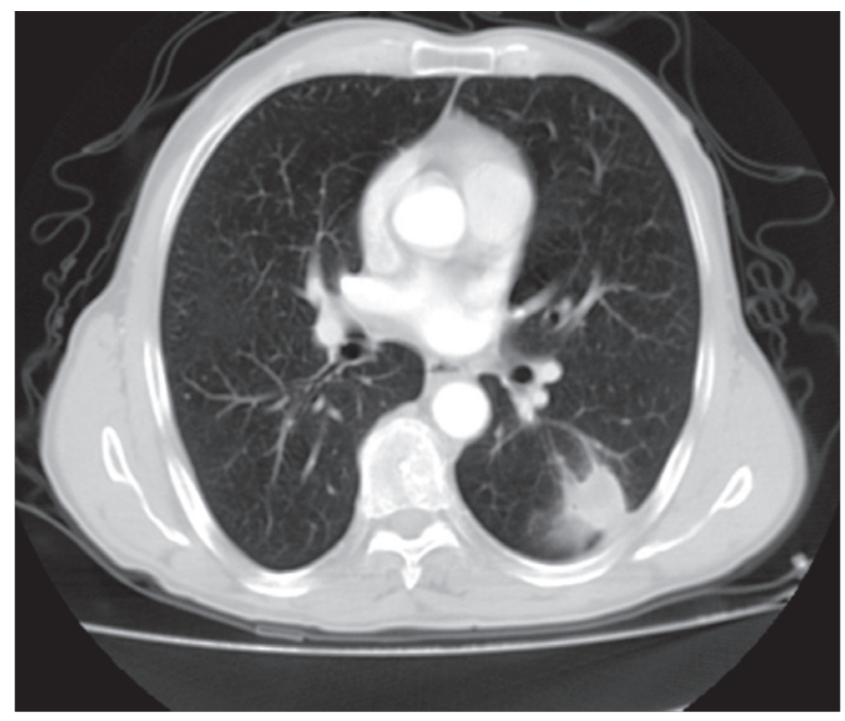

Figure 3. Thoracic computed tomography

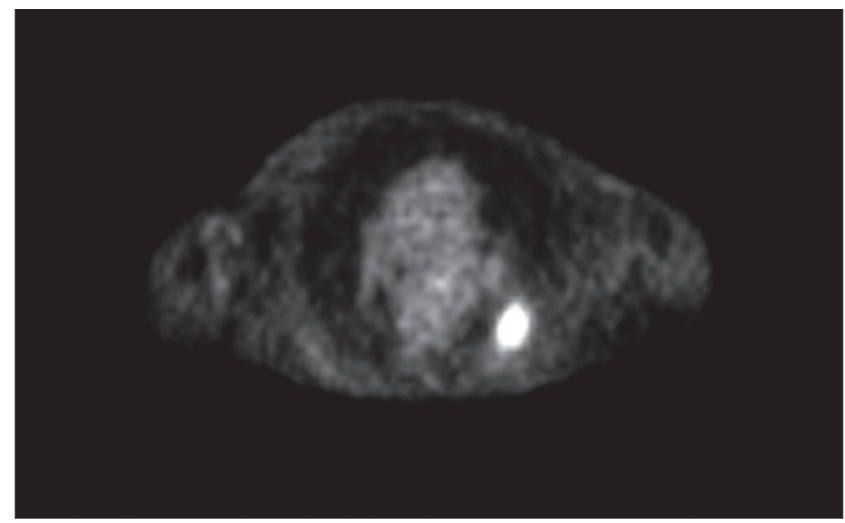

Figure 4. Positron emission tomography-computed tomography 


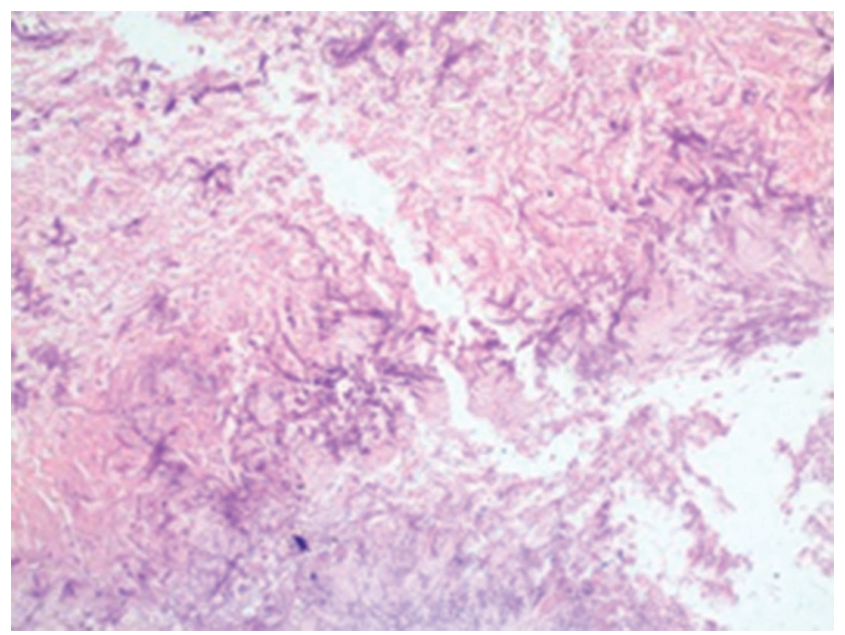

Figure 5. Histopathological picture of transthoracic fine needle aspiration biopsy

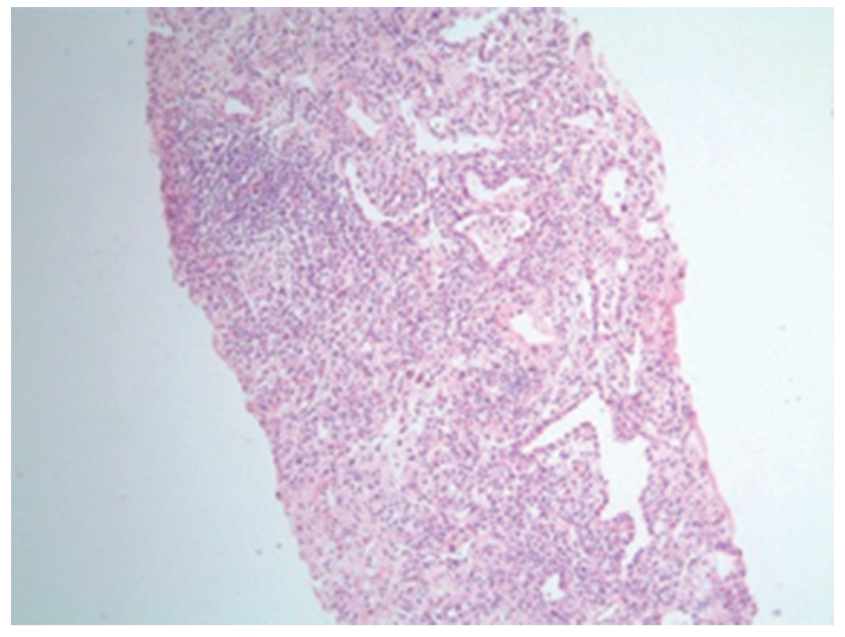

Figure 6. Histopathological picture of transthoracic fine needle aspiration biopsyaspiration biopsy

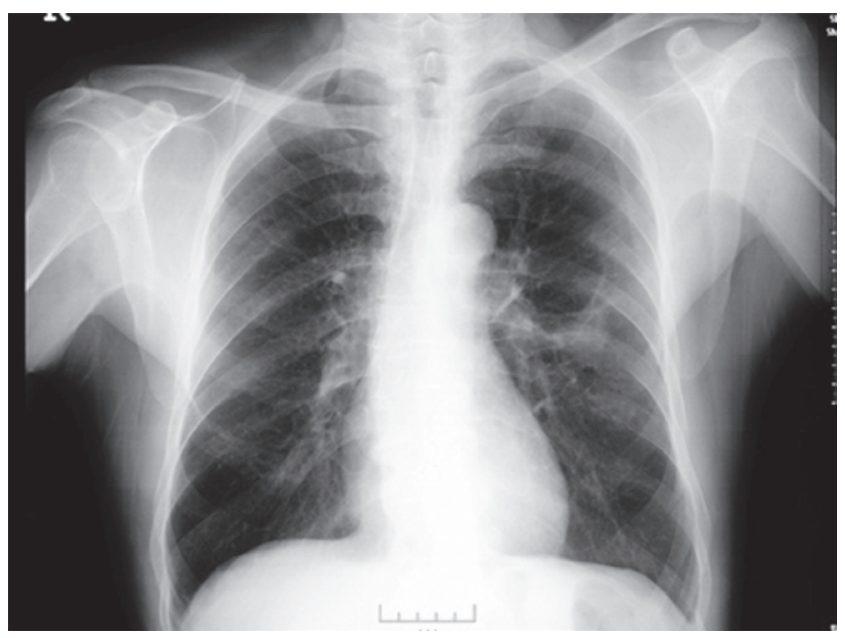

Figure 7. At the end of the fifth month of treatment acid treatment was implemented for five months. A significant regression was observed both clinically and radiologically at the end of the fifth month of treatment (Figure 7).

\section{Discussion}

Actinomycosis infection is a rare chronic, suppurative, and granulomatous disease.

Actinomyces israelii, which is a Gram-positive anaerobic bacterium and frequently present in the oropharyngeal flora, is the most common active microorganism (5). Poor oral hygiene, immunosuppression, and long-term use of intrauterine devices are the main predisposing factors (6). In our case, tooth retraction and poor oral hygiene were thought to be the main predisposing factors.

The disease is more common in individuals aged between 20 and 50 years. Apart from pelvic actinomycosis, the exact cause is still unknown, however, men are more affected than women (3:1). There is no predilection for race (7). Inconsistent with previous reports, our case was older than the reported cases in the literature.

Actinomycosis is a chronic infection characterized by the presence of fibrous tissue. As a result, it can be seen as mass-like dense granulation tissue and fibrosis (8). CT can be used as a guide, although most imaging methods are insufficient in the diagnosis. On $\mathrm{CT}$, a mass containing solid or an abscess foci can be detected (8). As in our case, radiological findings, and PET findings in PPA cases, may cause suspicion for a malignant disease, rather than an infection.

Ünsal et al. (9) reported a patient diagnosed with actinomycosis who underwent an operation due to a pulmonary mass. The authors reported the risk factors as type 2 diabetes mellitus and a decayed teeth. In another report, Yılmaz et al. (10) presented a patient diagnosed with actinomycosis who underwent an operation with a preliminary diagnosis of lung malignancy and who had no predisposing factors, except for epilepsy. In addition, Kaya et al. (11) reported a case of a patient diagnosed with pulmonary actinomycosis through TFNAB, as in our patient, with a preliminary diagnosis of a malignant mass, and in whom the main predisposing risk factor was diabetes mellitus.

Treatment of the disease requires long-term antibiotic treatment. Penicillin antibiotics are the fhe first option in medical treatment. In the next step, tetracycline, clindamycin, erythromycin, and lincomycin antibiotics can be used (12-16). Some authors suggest that the duration of treatment should be between six months and two years. Our patient was successfully treated with intravenous ampicillin-sulbactam for two weeks, followed by oral amoxicillin for five months. 
In conclusion, PPA is a rare condition and histopathological confirmation is necessary for clinical diagnosis. In the differential diagnosis of pulmonary masses, PPA should be considered in case of the presence of predisposing risk factors.

\section{Ethics}

Informed Consent: This study was conducted in accordance with Helsinki Declaration. Informed consent was not obtained.

Peer-review: Externally and internally peer-reviewed.

\section{Authorship Contributions}

Concept: P.M., N.A.M. Design: P.M., N.A.M. Data Collection or Processing: M.I.G. Analysis or Interpretation: P.M. Literature Search: P.M., N.A.M. Writing: P.M.

Conflict of Interest: No conflict of interest was declared by the authors.

Financial Disclosure: The authors declared that this study received no financial support.

\section{References}

1. Yang $X X$, Lin JM, Xu KJ, et al. Hepatic actinomycosis: report of one case and analysis of 32 previously reported cases. World J Gastroenterol 2014;20:16372-6.

2. Kaya D, Demirezen Ş, Beksaç MS. Aktinomikoza genel bir bakış. Türkiye Klinikleri J Med Sci 2009;29:510-9.

3. Mabeza GF, Macfarlane J. Pulmonary Actinomycosis. Eur Respir J 2003;21:545-51.

4. Hotchi M, Schwarz J. Characterization of actinomycotic granules by architecture and staining methods. Arch Pathol 1972;93:392-400
5. Laurent TH, Grandi P, Schnyder P. Abdominal actinomycosis associated with intrauterine device: CT features. Eur Radiol 1996;6:670-3.

6. Bennhoff DF. Actinomycosis: diagnostic and therapeutic considerations and a review of 32 cases. Laryngoscope 1984;94:1198.

7. http://www.emedicine.com/med/topic31.htm

8. Yoo-Kyung L, Jae-Man B, Yeon-Jin P. Pelvic actinomycosis with hydronephrosis and colon stricture simulating an advanced ovarian cancer. J Gynecol Oncol 2008;19:154-6.

9. Ünsal I, Anar C, Halilçolar H, ve ark. Toraks duvarına invaze bir pulmoner aktinomikoz: olgu sunumu. İzmir Göğüs Hastanesi Dergisi 2011;25:129-35.

10. Yılmaz A, Sahin S, Biber C, ve ark. Pulmonary Actinomycosis Imitating Malignancy in an Epileptic Patient. Turk Toraks Dergisi 2009;10:151-4.

11. Kaya H, Cetinkaya E, Ozgul G, ve ark. Maligniteyi Taklit Eden Bir Pulmoner Aktinomikoz Olgusu. Solunum Dergisi 2011;13:46-48.

12. Ünür M, Onur ÖD. Aktinomikoz: Ağız Hastalıklarının Teşhis ve Tedavisi. 1. baskı. İstanbul, Quintessence Yayıncılık, 2003, s. 175-77.

13. Kayser FH, Bienz KA, Eckert J, Zinkemagel RM. Medizinische Mikrobiologie. Stuttgart: Thieme, 1998, p. 252-54.

14. Burnett GW, Scherp HW. Oral Microbiology and Infectious Disease. 3th ed. Baltimore, 1968, p. 493-99.

15. Çetin ET. Infeksiyon Hastalıkları. İstanbul Tıp Fakültesi Klinik Ders Kitapları. Cilt 10. 3. baskı. İstanbul, 1979, s. 201-2.

16. Onul M. Sistemik Infeksiyon Hastalıkları. 2. Baskı. Ankara, 1983 , s.177-8. 